\title{
ACE Inhibitor and ARB Utilization and Expenditures in the Medicaid Fee-For-Service Program from 1991 to 2008
}

\author{
Boyang Bian, MS; Christina M.L. Kelton, PhD; Jeff J. Guo, PhD; and Patricia R. Wigle, PharmD
}

\begin{abstract}
BACKGROUND: Angiotensin-converting enzyme (ACE) inhibitors and angiotensin receptor blockers (ARBs) are widely prescribed for the treatment of hypertension and heart failure, as well as for kidney disease prevention in patients with diabetes mellitus and the management of patients after myocardial infarction.
\end{abstract}

OBJECTIVE: To (a) describe ACE inhibitor and ARB utilization and spending in the Medicaid fee-for-service program from 1991 through 2008, and (b) estimate the potential cost savings for the collective Medicaid programs from a higher ratio of generic ACE inhibitor utilization.

METHODS: A retrospective, descriptive analysis was performed using the National Summary Files from the Medicaid State Drug Utilization Data, which are composed of pharmacy claims that are subject to federally mandated rebates from pharmaceutical manufacturers. For the years 1991-2008, quarterly claim counts and expenditures were calculated by summing data for individual ACE inhibitors and ARBs. Quarterly per-claim expenditure as a proxy for drug price was computed for all brand and generic drugs. Market shares were calculated based on the number of pharmacy claims and Medicaid expenditures.

RESULTS: In the Medicaid fee-for-service program, ACE inhibitors accounted for $100 \%$ of the claims in the combined market for ACE inhibitors and ARBs in $1991,80.6 \%$ in 2000 , and $64.7 \%$ in 2008. The Medicaid expenditure per ACE inhibitor claim dropped from \$37.24 in 1991 to \$24.03 in 2008 when generics accounted for $92.5 \%$ of ACE inhibitor claims; after adjusting for inflation for the period from 1991 to 2008 , the real price drop was $59.2 \%$. Brand ACE inhibitors accounted for only $7.5 \%$ of the claims in 2008 for all ACE inhibitors but $32.1 \%$ of spending; excluding the effects of manufacturer rebates, Medicaid spending would have been reduced by $\$ 28.7$ million (9\%) in 2008 if all ACE inhibitor claims were generic. The average price per ACE inhibitor claim in 2008 was $\$ 24.03$ (\$17.64 per generic claim vs. $\$ 103.45$ per brand claim) versus $\$ 81.98$ per ARB claim. If the ACE inhibitor ratio had been $75 \%$ in 2008 rather than $64.7 \%$, the Medicaid program would have saved approximately $13 \%$ or about $\$ 41.8$ million, again excluding the effects of manufacturer rebates. If the ACE inhibitor ratio had been $90 \%$ in 2008, the cost savings for the combined Medicaid fee-forservice programs would have been about $33 \%$ or about $\$ 102.3$ million. The total cost savings opportunity with $100 \%$ generic ACE inhibitor utilization in 2008 and an ACE inhibitor ratio of $75 \%$ was $\$ 75.1$ million (24\%) or $\$ 142.3 \mathrm{M}$ (46\%) with a $90 \%$ ACE inhibitor ratio.

CONCLUSION: Factors that affect Medicaid spending by contributing to increased utilization of ACE inhibitors and ARBs, such as the rising prevalence of hypertension, heart disease, and diabetes, can be offset by reduction in the average price attained through a higher proportion of ACE inhibitors and a higher percentage of generic versus brand ACE inhibitors.

J Manag Care Pharm. 2010;16(9):671-79

Copyright $\odot 2010$, Academy of Managed Care Pharmacy. All rights reserved.

\section{What is already known about this subject}

- Angiotensin-converting enzyme (ACE) inhibitors and angiotensin receptor blockers (ARB)s are both widely used in the treatment of hypertension and heart failure and in the prevention of macrovascular and microvascular cardiovascular outcomes associated with hypertension and diabetes. In 2009, ACE inhibitors were the fourth most utilized drug class in the United States with 162.8 million prescriptions, and ARBs were the eleventh most utilized drug class with 82.5 million prescriptions.

- Utilization of ACE inhibitors and ARBs may be cost-effective for their approved indications particularly when generic drugs are used in place of brand name drugs. Captopril was the first generic ACE inhibitor at year-end 1995, but it was almost 5 years before the class became relatively inexpensive with the introduction of generic enalapril in 2000 Q3 and lisinopril in 2002 Q3. The first generic ARB (losartan and losartan/HCTZ) entered the U.S. market in April 2010.

\section{What this study adds}

- In 2008, state Medicaid fee-for-service programs spent approximately $\$ 310$ million for both ACE inhibitors ( $\$ 108$ million) and ARBs ( $\$ 202$ million). ARBs represented only 35.3\% of the total claims but $65.1 \%$ of the total combined expenditure because of the higher average price per claim, $\$ 81.98$ for ARBs versus $\$ 24.03$ for ACE inhibitors.

- With generic drug entry for the ACE inhibitors, the average price per ACE inhibitor claim declined from approximately \$37 in 1991 to $\$ 24$ in 2008 , while the average price for ARB claims increased from approximately $\$ 38$ in 1995 to $\$ 82$ in 2008

- If the $7.5 \%$ of all ACE inhibitor claims that were brand in 2008 were substituted with generic ACE inhibitors, the average price per claim would have been $\$ 17.64$ rather than $\$ 24.03$, representing a savings opportunity of $\$ 28.7$ million (9\%) for the Medicaid fee-for-service programs for combined ACE inhibitor-ARB spending. The total cost savings opportunity was as much as $\$ 142.3$ million (46\%), attainable with $100 \%$ generic ACE inhibitors and a $90 \%$ ratio of ACE inhibitors to total ARB and ACE inhibitors, associated with a reduction in the average price per claim from $\$ 44.52$ to $\$ 24.07$, excluding the effects of manufacturer rebate payments. 
$\mathrm{H}$ ypertension is a major risk factor for the development of cardiovascular disease, including coronary artery disease, stroke, and heart failure. ${ }^{1}$ According to the American Heart Association, there were 74.5 million people with hypertension (representing a $33.6 \%$ adult prevalence rate) and 5.8 million with heart failure in the United States (a $2.6 \%$ adult prevalence rate) in $2006 .{ }^{2}$ In 2007 , an estimated 17.5 million people in the United States were diagnosed with type 1 or type 2 diabetes, a disease that often coexists with hypertension. ${ }^{3}$

Although thiazide-type diuretics are recommended as first-line therapy for uncomplicated hypertension, patients with stage 2 hypertension (systolic blood pressure equal to or greater than $160 \mathrm{mmHg}$ ) should be treated with a combination of 2 antihypertensive medications. ${ }^{1}$ Angiotensin-converting enzyme (ACE) inhibitors are widely used in the treatment of hypertension. Their effect on the renin-angiotensin-aldosterone system, combined with improved ventricular remodeling, make ACE inhibitors an attractive option for heart failure patients, as well as for patients who have had a myocardial infarction. Multiple effects on the kidney, including a decrease in renovascular resistance, make ACE inhibitors appropriate also for decreasing the progression of nephropathy in patients with diabetes. ${ }^{4}$ Labeled indications besides hypertension for the various ACE inhibitors include congestive heart failure; to improve survival following myocardial infarction; stable coronary artery disease; risk reduction for myocardial infarction, stroke, and death from cardiovascular causes; and left ventricular dysfunction after myocardial infarcation. ${ }^{5}$

The first ACE inhibitor, captopril (Capoten), was approved by the U.S. Food and Drug Administration (FDA) in 1981 to treat hypertension and enjoyed market exclusivity for almost 5 years until the second ACE inhibitor, enalapril (Vasotec), was introduced at the end of 1985. Following enalapril, a number of other brand ACE inhibitors entered the market (Table 1). The latest FDA-approved ACE inhibitor was trandolapril (Mavik) in 1996. Many of the ACE inhibitors are also marketed as combination drugs either with a diuretic (e.g., Lotensin-HCT; benazepril and hydrochlorothiazide [HCTZ]) or with a calcium channel blocker (e.g., Lotrel; benazepril and amlodipine). ${ }^{6}$ All of the ACE inhibitors now have generic equivalents in 2010. According to IMS Health, of 3.9 billion prescriptions dispensed in the United States in 2009, 162.8 million (4.2\%) were for ACE inhibitors. ${ }^{7}$ Only 3 drug classes had more prescriptions dispensed in 2009: lipid regulators, codeine and combinations, and antidepressants.

Angiotensin receptor blockers (ARBs), a newer class of antihypertensives, are also widely prescribed either as monotherapy or in combination with a diuretic or calcium channel blocker. Along with hypertension, labeled indications for the ARBs include heart failure, nephropathy in type-2 diabetic patients, left ventricular hypertrophy, reduction in the risk of stroke, and reduction in cardiovascular mortality following a myocardial infarction. ${ }^{5}$ ARBs are also prescribed for patients who cannot tolerate an ACE inhibitor-induced cough. ${ }^{8}$ On April 14, 1995, the FDA approved the first ARB, losartan (Cozaar), for clinical use in the United States. Cozaar dominated the ARB market briefly (Table 1). The most recent FDA approval of an ARB was olmesartan (Benicar) in April 2002.6 Although none of the ARBs experienced generic entry during the study period, generic losartan and losartan/HCTZ have been available in the U.S. market since April 2010. ${ }^{9}$

ARBs have not been shown to be more effective than ACE inhibitors in blood-pressure reduction or in slowing the progression of renal disease or slowing the progression to type-2 diabetes. ${ }^{5}$ ARBs are associated with a lower incidence of cough, but the absolute rates of cough are often low including the headto-head trial of ramipiril (4.2\%) versus telmisartan (1.1\%) in ONTARGET (Ongoing Telmisartan Alone and in Combination with Ramipril Global Endpoint Trial). ${ }^{10}$ In 2009, 82.5 million prescriptions were dispensed for ARBs (which represent approximately $2 \%$ of all U.S. prescriptions), and the ARB class was ranked eleventh in prescription volume. ${ }^{7}$ Cardiovascular mortality has been decreased by certain antihypertensive medications, including ACE inhibitors and ARBs. ${ }^{11}$

Due to its high and rising prevalence, hypertension is an expensive disease. Moreover, the growing acceptance of ACE inhibitors and ARBs as first-line therapies in the treatment of hypertension coupled with a decline in cardiovascular disease mortality (leading to longer use of the antihypertensive medications) imply higher expenditures for drug treatment. A number of chronic disease conditions have propelled spending on prescription drugs, ${ }^{12}$ and Medicaid and Medicare combined spending on outpatient prescription drugs was over $\$ 70$ billion in 2008, much higher than 2 decades ago (Figure 1). Although an abrupt drop in Medicaid expenditures accompanied the transfer of dual Medicaid-Medicare eligibles to Medicare Part D in 2006, an upward trend in Medicaid spending was seen between 2006 and 2008.

In response to rising prescription drug expenditures, state Medicaid programs have developed a variety of cost-containment strategies, including beneficiary cost sharing, preferred drug lists, formularies, requiring generic substitution, and prior authorization (PA) for certain types of medication. These strategies are not standardized, and each state has its own set of policies. ${ }^{13}$ Fischer and Avorn (2003) estimated that there were potential cost savings for Medicaid of $\$ 450$ million from greater overall use of generic drugs. ${ }^{14}$ Due to the therapeutic interchangeability of ACE inhibitors and ARBs, coupled with the availability of inexpensive generic ACE inhibitors, many private payers require PA or step-therapy for ARBs. ${ }^{15,16}$ Hence, the present study has 2 objectives: (a) describe ACE inhibitor 
and ARB utilization and spending in the Medicaid fee-forservice program from 1991 through 2008, and (b) estimate the potential cost savings for the Medicaid programs from a higher ratio of generic ACE inhibitor utilization.

\section{Methods}

A retrospective, descriptive analysis was performed for the years 1991-2008 using the publicly available National Summary Files from the Medicaid State Drug Utilization Data maintained by the Centers for Medicare \& Medicaid Services. The database covers Medicaid beneficiaries in 49 states (all except Arizona) and the District of Columbia and is restricted to outpatient pharmaceuticals. ${ }^{17}$ The National Summary Files in the present study were compiled by aggregating state databases; the method is described in detail below. Since the data are collected as part of the Medicaid Rebate Program, they include fee-for-service but not managed Medicaid pharmacy claims. States differ in how their drug benefit programs are managed. Arizona, for example, is not included in the database because it is $100 \%$ managed care (i.e., Arizona Medicaid pharmacy claims are not eligible for federally negotiated manufacturer rebates). ${ }^{18}$ The database appeared to contain coding errors in 2006 (all quarters) and 2007 Q3. During those 5 quarters, for some individual drugs including ACE inhibitors and ARBs, expenditures were incorrectly reported; hence, using the utilization data, which seemed to be correctly reported, we re-estimated expenditures for these 5 calendar quarters. For example, taking an average of per-unit (e.g., individual capsule or tablet) expenditure (i.e., pharmacy reimbursement) for quarters before and after the quarter in which a coding error occurred, we multiplied that average by the number of units. In this way, we came up with pharmacy reimbursement estimates that had better face validity. The general results from the present study were not affected by this small amount of data cleaning.

Each data record included the National Drug Code (NDC) number, drug name (trade or generic), year and quarter of Medicaid expenditure, number of pharmacy claims, number of units (e.g., individual capsules or tablets), and total pharmacy reimbursement amount, including drug cost and dispensing fee. The first 5 digits of the NDC number identified the drug manufacturer, while the remaining digits identify specific drug product by strength, dose formulation, and packaging. We searched the database for all ACE inhibitors and ARBs using both trade name and generic name (Table 1). For each of the drugs in Table 1, and for the ACE inhibitor and ARB classes overall, quarterly claim counts and reimbursement amounts were calculated by summing data across individual NDCs for each of the drugs and then for each class of drugs, respectively. Data for all the generic versions of each drug were aggregated, and all the combination drugs (with diuretic or calcium channel blocker) were aggregated with their stand-alone counter-

\section{TABLE 1$)$ ACE Inhibitors and ARBs} by FDA Approval Date

\begin{tabular}{|c|c|c|c|c|}
\hline $\begin{array}{c}\text { Generic } \\
\text { Name }\end{array}$ & $\begin{array}{l}\text { Brand } \\
\text { Name }\end{array}$ & $\begin{array}{l}\text { Brand Drug } \\
\text { Manufacturer }\end{array}$ & $\begin{array}{c}\text { FDA } \\
\text { Approvala }^{2}\end{array}$ & $\begin{array}{c}\begin{array}{c}\text { First Quarter } \\
\text { of Generic } \\
\text { Entry }\end{array} \\
\end{array}$ \\
\hline \multicolumn{5}{|c|}{ ACE Inhibitors } \\
\hline Captopril & $\begin{array}{c}\text { Capoten } \\
\text { Capozide }^{b}\end{array}$ & $\begin{array}{l}\text { BMS } \\
\text { BMS } \\
\end{array}$ & $\begin{array}{l}04 / 06 / 81 \\
10 / 12 / 84\end{array}$ & 1995 Q4 \\
\hline Enalapril & $\begin{array}{c}\text { Vasotec } \\
\text { Vaseretic }^{b} \\
\text { Lexxelc }^{c}\end{array}$ & $\begin{array}{c}\text { Merck } \\
\text { Merck } \\
\text { AstraZeneca }\end{array}$ & $\begin{array}{l}12 / 24 / 85 \\
10 / 31 / 86 \\
12 / 27 / 96 \\
\end{array}$ & 2000 Q3 \\
\hline Lisinopril & $\begin{array}{c}\text { Prinivil } \\
\text { Zestril } \\
\text { Prinzide }^{b} \\
\text { Zestoretic }^{b}\end{array}$ & $\begin{array}{c}\text { Merck } \\
\text { AstraZeneca } \\
\text { Merck } \\
\text { AstraZeneca }\end{array}$ & $\begin{array}{l}12 / 29 / 87 \\
05 / 19 / 88 \\
02 / 16 / 89 \\
09 / 20 / 90 \\
\end{array}$ & 2002 Q3 \\
\hline Ramipril & Altace & King & $01 / 28 / 91$ & NA \\
\hline Fosinopril & $\begin{array}{c}\text { Monopril } \\
\text { Monopril-HCT }\end{array}$ & $\begin{array}{l}\text { BMS } \\
\text { BMS }\end{array}$ & $\begin{array}{l}05 / 16 / 91 \\
11 / 30 / 94\end{array}$ & 2003 Q4 \\
\hline Benazepril & $\begin{array}{c}\text { Lotensin } \\
\text { Lotensin-HCT } \\
\text { Lotrelc }^{\mathrm{c}} \\
\end{array}$ & $\begin{array}{l}\text { Novartis } \\
\text { Novartis } \\
\text { Novartis }\end{array}$ & $\begin{array}{l}6 / 25 / 91 \\
5 / 19 / 92 \\
03 / 3 / 95 \\
\end{array}$ & 2004 Q1 \\
\hline Quinapril & $\begin{array}{c}\text { Accupril } \\
\text { Accuretic }^{b}\end{array}$ & $\begin{array}{l}\text { Pfizer } \\
\text { Pfizer }\end{array}$ & $\begin{array}{l}11 / 19 / 91 \\
12 / 28 / 99 \\
\end{array}$ & 2004 Q4 \\
\hline$\underline{\text { Perindopril }}$ & Aceon & Solvay & $12 / 30 / 93$ & NA \\
\hline Moexipril & $\begin{array}{l}\text { Univasc } \\
\text { Uniretic }^{b}\end{array}$ & $\begin{array}{l}\text { Schwarz } \\
\text { Pharma } \\
\text { Schwarz } \\
\text { Pharma }\end{array}$ & $\begin{array}{l}\text { 4/19/95 } \\
6 / 27 / 97\end{array}$ & 2003 Q3 \\
\hline Trandolapril & $\begin{array}{l}\text { Mavik } \\
\text { Tarkab }^{\circ}\end{array}$ & $\begin{array}{l}\text { Knoll } \\
\text { Knoll } \\
\end{array}$ & $\begin{array}{l}04 / 26 / 96 \\
10 / 22 / 96 \\
\end{array}$ & 2007 Q1 \\
\hline \multicolumn{5}{|c|}{ ARBs } \\
\hline Losartan & $\begin{array}{c}\text { Cozaar } \\
\text { Hyzaarb }^{b} \\
\end{array}$ & $\begin{array}{l}\text { Merck } \\
\text { Merck }\end{array}$ & $\begin{array}{l}04 / 14 / 95 \\
04 / 28 / 95 \\
\end{array}$ & $2010 Q^{d}$ \\
\hline Valsartan & $\begin{array}{c}\text { Diovan } \\
\text { Diovan HCT }\end{array}$ & $\begin{array}{l}\text { Novartis } \\
\text { Novartis }\end{array}$ & $\begin{array}{l}12 / 23 / 96 \\
03 / 06 / 98\end{array}$ & NA \\
\hline Irbesartan & $\begin{array}{c}\text { Avapro } \\
\text { Avalide }^{\mathrm{b}} \\
\end{array}$ & $\begin{array}{l}\text { Sanofi-Aventis } \\
\text { Sanofi-Aventis }\end{array}$ & $\begin{array}{l}09 / 30 / 97 \\
09 / 30 / 97 \\
\end{array}$ & NA \\
\hline Eprosartan & $\begin{array}{c}\text { Teveten } \\
\text { Teveten HCT }\end{array}$ & $\begin{array}{l}\text { Abbott } \\
\text { Abbott }\end{array}$ & $\begin{array}{l}12 / 22 / 97 \\
11 / 01 / 01 \\
\end{array}$ & NA \\
\hline Candesartan & $\begin{array}{c}\text { Atacand } \\
\text { Atacand } \mathrm{HCT}^{\mathrm{b}}\end{array}$ & $\begin{array}{l}\text { AstraZeneca } \\
\text { AstraZeneca }\end{array}$ & $\begin{array}{l}06 / 04 / 98 \\
09 / 05 / 00 \\
\end{array}$ & NA \\
\hline Telmisartan & Micardis $\mathrm{HCT}^{\mathrm{b}}$ & $\begin{array}{l}\text { Boehringer } \\
\text { Ingelheim } \\
\text { Boehringer } \\
\text { Ingelheim }\end{array}$ & $\begin{array}{l}11 / 10 / 98 \\
11 / 17 / 00\end{array}$ & NA \\
\hline Olmesartan & $\begin{array}{c}\text { Benicar } \\
\text { Benicar HCT } \\
\text { Azorc } \\
\end{array}$ & $\begin{array}{l}\text { Sankyo } \\
\text { Sankyo } \\
\text { Sankyo }\end{array}$ & $\begin{array}{l}04 / 25 / 02 \\
06 / 05 / 03 \\
09 / 26 / 07 \\
\end{array}$ & NA \\
\hline
\end{tabular}

a Approval dates found at: http://www.accessdata.fda.gov/scripts/cder/drugsatfda/index.cfm. ${ }^{6}$

${ }^{b}$ Contains hydrochlorothiazide.

cContains calcium channel blocker.

${ }^{d}$ Generic losartan and losartan/hydrochlorothiazide were introduced in April 2010. $A C E=$ angiotensin-converting enzyme; $A R B=$ angiotensin II receptor blocker; BMS = Bristol-Myers Squibb; FDA = U.S. Food and Drug Administration; HCT = hydrochlorothiazide; NA = not applicable.

parts (e.g., claims for lisinopril/HCTZ were combined with those for lisinopril). Market shares were calculated based on both number of prescriptions and Medicaid payments. 


\section{FIGURE 1 Annual Medicaid and Medicare Spending for Prescription Drugs: 1991-2008}

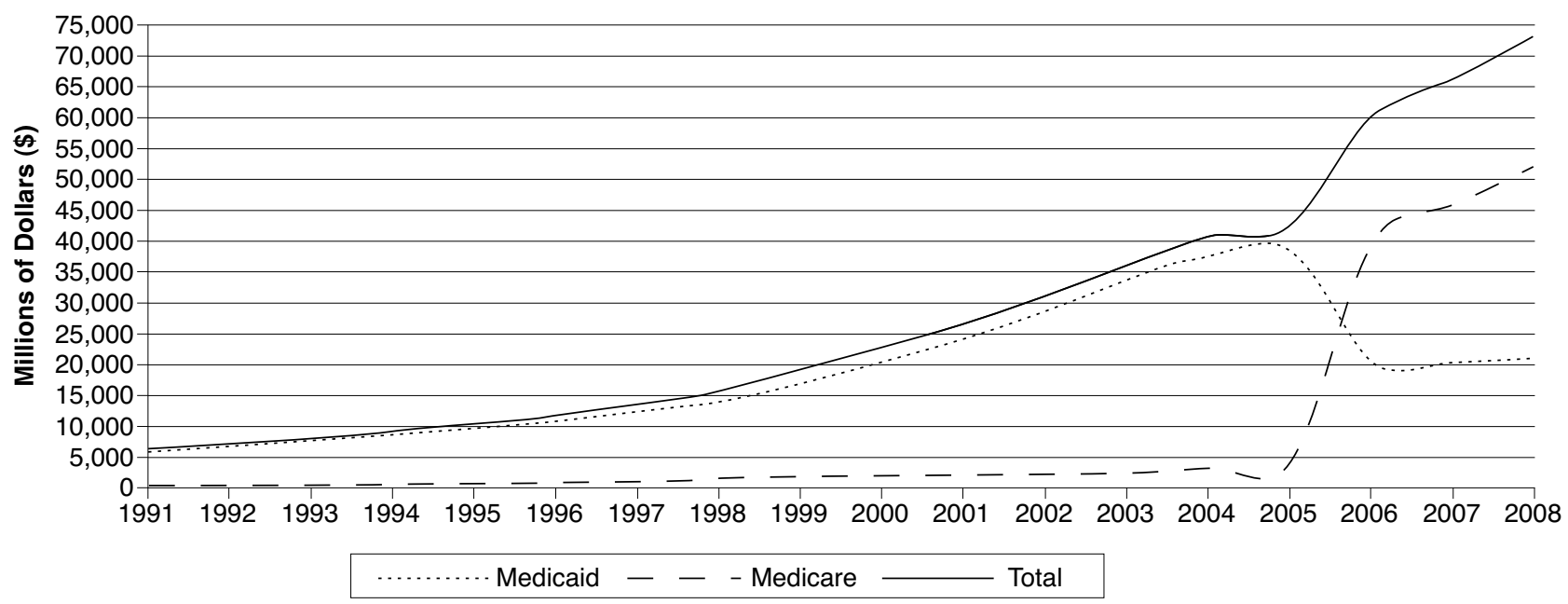

Source: National Health Expenditures by Type of Service and Source of Funds, CY 1960-2008, found at: https://www.cms.gov/NationalHealthExpendData/02_NationalHealthAccountsHistorical.asp\#TopOfPage.

Quarterly per-claim pharmacy reimbursement, as a proxy for drug price, was computed for all brand and generic ACE inhibitors and ARBs. Pharmacy reimbursements include the drug ingredient cost and dispensing fee but do not include manufacturer rebates (i.e., federally mandated rebates and supplemental state rebates have not been subtracted). All the data analyses were conducted using the SAS software package for Windows (Version 9.1.3, SAS Institute Inc., Cary, NC). Excel 2007 (Microsoft, Redmond, WA) was used to further develop the data.

\section{Results}

Table 2 shows prescription market shares for both the ACE inhibitor and ARB classes of drugs. Whereas ACE inhibitors had $100 \%$ of the Medicaid market in the number of claims from 1991-1994, their share fell to $64.7 \%$ by 2008 . The share of brand drug prescriptions exceeded the share of generic prescriptions for ACE inhibitors through 2002. In 2003, this relationship reversed, and in 2008, 92.5\% of Medicaid feefor-service claims for ACE inhibitors were generic. All of the ARBs were still under patent and without generic competition at the end of the study period in 2008. Table 2 also shows payment market shares for the ACE inhibitors and ARBs. For the first time in 2007, and continuing in 2008, Medicaid spending on generic ACE inhibitors exceeded its spending on brand drugs in this class. Although brand drugs represented only $7.5 \%$ of the ACE inhibitor claims in 2008, they accounted for $32.1 \%$ of expenditures because their average price (\$103.45) was almost 6 times the average generic ACE inhibitor price (\$17.64; Table 3).

By 2005, the dollar market share for ARBs was higher than for ACE inhibitors and remained higher through 2008. In 2005, the ARBs accounted for $51.5 \%$ of Medicaid expenditures in the 2 drug classes rising to $65.1 \%$ in 2008 .

The last 3 columns of Table 2 show the annual pharmacy payments (prices) per claim for the ACE inhibitors, ARBs, and for both drug classes combined. In 1991, an average pharmacy claim for an ACE inhibitor cost these Medicaid programs \$37.24. In 2008, the average price per claim had fallen to $\$ 24.03$. After adjusting both values by their year-appropriate consumer price index (CPI) values (136.2 and 215.3 base 19821984 for 1991 and 2008, respectively, for an inflation rate of $58.1 \%),{ }^{19}$ Medicaid enjoyed a real price drop of $59.2 \%$ for ACE inhibitors in 2008 compared with 1991. In contrast, the average price of an ARB prescription rose from \$38.24 in 1995 to $\$ 81.98$ in 2008. After adjusting by the change in the CPI (from 152.4 in 1995 to 215.3 in 2008, for an inflation rate of $41.3 \%$ ), the average ARB price rose in real terms by $51.7 \%$ from 1995 to 2008. Figure 2 shows the trends in average ACE inhibitor and average ARB prices along with the trend in the CPI over the same time period from 1991 to 2008.

In 2008, the Medicaid programs combined spent $\$ 309.8$ million on ACE inhibitors and ARBs, with $64.7 \%$ of the claims for ACE inhibitors. At an average price per claim of $\$ 24.03$, ACE inhibitors were significantly cheaper than the ARBs, which cost an average of $\$ 81.98$ per claim. If the ACE inhibitor share had been reduced from $35.3 \%$ to $25.0 \%$, an attainable goal, ${ }^{20}$ the average price per claim would have fallen from 
TABLE 2 Annual Medicaid Claims and Expenditures for ACE Inhibitors and ARBs: 1991-2008

\begin{tabular}{|c|c|c|c|c|c|c|c|c|c|c|c|c|c|}
\hline \multirow[b]{2}{*}{ Year } & \multicolumn{2}{|c|}{$\begin{array}{l}\text { Utilization and Spending: } \\
\text { ACE Inhibitors and ARBs }\end{array}$} & \multicolumn{4}{|c|}{ Share of Generic ACE Inhibitors } & \multicolumn{4}{|c|}{$\begin{array}{c}\text { Market Shares of ACE Inhibitors and } \\
\text { ARBs }\end{array}$} & \multicolumn{3}{|c|}{$\begin{array}{l}\text { Average Prices Per Claim for } \\
\text { ACE Inhibitors and ARBs }\end{array}$} \\
\hline & $\begin{array}{l}\text { Number of } \\
\text { Claims }\end{array}$ & Expenditures & $\begin{array}{c}\text { Brand } \\
\text { ACE } \\
\text { Inhibitor } \\
\text { Claim } \\
\%\end{array}$ & $\begin{array}{c}\text { Generic } \\
\text { ACE } \\
\text { Inhibitor } \\
\text { Claim } \\
\%\end{array}$ & $\begin{array}{c}\text { Brand } \\
\text { ACE } \\
\text { Inhibitor } \\
\text { Spending } \\
\%\end{array}$ & $\begin{array}{c}\text { Generic } \\
\text { ACE } \\
\text { Inhibitor } \\
\text { Spending } \\
\%\end{array}$ & $\begin{array}{c}\text { ACE } \\
\text { Inhibitor } \\
\text { Claim } \\
\%\end{array}$ & $\begin{array}{c}\text { ARB } \\
\text { Claim } \\
\%\end{array}$ & $\begin{array}{c}\text { ACE } \\
\text { Inhibitor } \\
\text { Spending } \\
\%\end{array}$ & $\begin{array}{c}\text { ARB } \\
\text { Spending } \\
\%\end{array}$ & $\begin{array}{c}\text { ACE } \\
\text { Inhibitor }\end{array}$ & ARB & $\begin{array}{l}\text { Combined } \\
\text { ACE } \\
\text { Inhibitor } \\
\text { and ARB }\end{array}$ \\
\hline 1991 & $4,812,732$ & $\$ 179,228,516$ & $100.0 \%$ & $0.0 \%$ & $100.0 \%$ & $0.0 \%$ & $100.0 \%$ & $0.0 \%$ & $100.0 \%$ & $0.0 \%$ & $\$ 37.24$ & & $\$ 37.24$ \\
\hline 1992 & $6,100,269$ & $\$ 236,948,154$ & $99.0 \%$ & $1.0 \%$ & $99.2 \%$ & $0.8 \%$ & $100.0 \%$ & $0.0 \%$ & $100.0 \%$ & $0.0 \%$ & $\$ 38.84$ & & $\$ 38.84$ \\
\hline 1993 & $6,768,406$ & $\$ 270,943,988$ & $97.3 \%$ & $7 \%$ & $97.8 \%$ & $2 \%$ & $100.0 \%$ & $0.0 \%$ & $100.0 \%$ & $0.0 \%$ & $\$ 40.03$ & & $\$ 40.03$ \\
\hline 1994 & $6,980,174$ & $\$ 281,378,322$ & $96.5 \%$ & $3.5 \%$ & $96.9 \%$ & $3.1 \%$ & $100.0 \%$ & $0.0 \%$ & $100.0 \%$ & $0.0 \%$ & $\$ 40.31$ & & $\$ 40.31$ \\
\hline 1995 & $7,600,760$ & $\$ 312,848,726$ & $96.1 \%$ & $3.9 \%$ & $96.6 \%$ & $3.4 \%$ & $99.6 \%$ & $0.4 \%$ & $99.6 \%$ & $0.4 \%$ & $\$ 41.17$ & $\$ 38.24$ & $\$ 41.16$ \\
\hline 1996 & $7,575,753$ & $\$ 296,581,719$ & $82.1 \%$ & $17.9 \%$ & $85.5 \%$ & $14.5 \%$ & $98.1 \%$ & $1.9 \%$ & $98.0 \%$ & $2.0 \%$ & $\$ 39.11$ & $\$ 41.10$ & $\$ 39.15$ \\
\hline 1997 & $8,792,962$ & $\$ 312,588,794$ & $78.4 \%$ & $21.6 \%$ & $87.5 \%$ & $12.5 \%$ & $92.9 \%$ & $7.1 \%$ & $91.3 \%$ & $8.7 \%$ & $\$ 34.93$ & $\$ 43.72$ & $\$ 35.55$ \\
\hline 1998 & $10,417,985$ & $\$ 365,062,415$ & $88.8 \%$ & $11.2 \%$ & $96.6 \%$ & $3.4 \%$ & $88.3 \%$ & $11.7 \%$ & $84.7 \%$ & $15.3 \%$ & $\$ 33.60$ & $\$ 46.00$ & $\$ 35.04$ \\
\hline 1999 & $11,744,983$ & $\$ 438,141,415$ & $91.1 \%$ & & $97.2 \%$ & & & & $79.6 \%$ & $20.4 \%$ & $\$ 35.24$ & $\$ 48.37$ & $\$ 37.30$ \\
\hline 2000 & $13,720,387$ & $0,752,819$ & $.0 \%$ & & & & $80.6 \%$ & & & & $\$ 35.78$ & & 8.68 \\
\hline 2001 & $17,087,892$ & $\$ 678,945,950$ & $74.9 \%$ & $25.1 \%$ & $77.1 \%$ & $22.9 \%$ & $78.6 \%$ & $21.4 \%$ & $71.3 \%$ & $28.7 \%$ & $\$ 36.06$ & $\$ 53.18$ & $\$ 39.73$ \\
\hline 2002 & $19,866,643$ & $\$ 804,525,700$ & $67.8 \%$ & $32.2 \%$ & $73.9 \%$ & $26.1 \%$ & $75.5 \%$ & $24.5 \%$ & $66.3 \%$ & $33.7 \%$ & $\$ 35.59$ & $\$ 55.59$ & $\$ 40.50$ \\
\hline 2003 & $22,717,810$ & $\$ 898,430,207$ & $45.6 \%$ & $54.4 \%$ & $61.3 \%$ & $38.7 \%$ & $72.0 \%$ & $28.0 \%$ & $58.4 \%$ & $41.6 \%$ & $\$ 32.07$ & $\$ 58.78$ & $\$ 39.55$ \\
\hline 2004 & $25,052,642$ & $\$ 1,001,525,549$ & $31.1 \%$ & $68.9 \%$ & $54.4 \%$ & $45.6 \%$ & $70.0 \%$ & $30.0 \%$ & $53.4 \%$ & $46.6 \%$ & $\$ 30.48$ & $\$ 62.18$ & $\$ 39.98$ \\
\hline 2005 & $24,382,606$ & $\$ 1,000,142,045$ & $20.6 \%$ & $79.4 \%$ & $50.0 \%$ & $50.0 \%$ & $67.7 \%$ & $32.3 \%$ & $48.5 \%$ & $51.5 \%$ & $\$ 29.36$ & $\$ 65.51$ & $\$ 41.02$ \\
\hline 2006 & $8,612,352$ & $\$ 390,270,946$ & $19.3 \%$ & & $61.4 \%$ & & $66.0 \%$ & $34.0 \%$ & & $46.0 \%$ & $\$ 37.06$ & $\$ 61.36$ & $\$ 45.32$ \\
\hline 2007 & $7,232,010$ & $\$ 368,784,282$ & $16.9 \%$ & $83.1 \%$ & $45.7 \%$ & & & & & $57.7 \%$ & $\$ 33.13$ & $\$ 84.33$ & $\$ 50.99$ \\
\hline 2008 & $6,959,548$ & $\$ 309,842,354$ & $7.5 \%$ & $92.5 \%$ & $32.1 \%$ & $67.9 \%$ & $64.7 \%$ & $35.3 \%$ & $34.9 \%$ & $65.1 \%$ & $\$ 24.03$ & $\$ 81.98$ & $\$ 44.52$ \\
\hline
\end{tabular}

Source: State Drug Utilization Data found at: http://www.cms.gov/MedicaidDrugRebateProgram/SDUD/list.asp. ${ }^{17}$

$A C E=$ angiotensin-converting enzyme; $A R B=$ angiotensin II receptor blocker .

$\$ 44.52$ to $\$ 38.52$, and Medicaid program expenditures would have been $\$ 41.8$ million less in 2008 . The savings opportunity was $\$ 102.3$ million in 2008 if the ACE inhibitor ratio had been $90 \%$, with a reduction in the average price per claim from $\$ 44.52$ to $\$ 29.83$.

On top of these savings, there are some additional savings from a higher percentage of generic, versus brand, ACE inhibitor prescriptions. In 2008, there were 335,925 claims for brand ACE inhibitors at an average price of $\$ 103.45$ per claim, compared with the $\$ 17.64$ average for generic ACE inhibitor claims (Table 3). Multiplying the number of claims by the difference in price of $\$ 85.81$ per claim means that there was an additional unrealized savings opportunity of $\$ 28.7$ million if all ACE inhibitors were dispensed as generic in 2008.

The maximum savings opportunity in 2008, attainable through greater use of generic ACE inhibitors, was $\$ 75.1$ million if all ACE inhibitors were dispensed as generic and $75 \%$ of the combined ACE inhibitors and ARBs were dispensed as ACE inhibitors; the average price per claim would have been $\$ 33.73$ instead of $\$ 44.52$. Even higher utilization of generic ACE inhibitors at $90 \%$ of the combined ACE inhibitors and ARBs would have produced cost savings of $\$ 142.3$ million (46\%), associated with a reduction in the average price per claim from $\$ 44.52$ to $\$ 24.07$.

By dividing total reimbursement by the number of claims,

\section{TABLE 3 Brand and Generic Average Prices Per Claim in 2008}

\begin{tabular}{|c|c|c|}
\hline Drug & Average Brand Price & Average Generic Price \\
\hline \multicolumn{3}{|c|}{ ACE Inhibitors ${ }^{a}$} \\
\hline Benazepril & $\$ 118.73$ & $\$ 20.39$ \\
\hline Captopril & $\$ 175.38$ & $\$ 8.16$ \\
\hline Enalapril & $\$ 106.53$ & $\$ 16.58$ \\
\hline Fosinopril & $\$ 63.00$ & $\$ 26.75$ \\
\hline Lisinopril & $\$ 50.16$ & $\$ 12.36$ \\
\hline Moexipril & $\$ 49.06$ & $\$ 38.70$ \\
\hline Perindopril & $\$ 80.26$ & NA \\
\hline Quinapril & $\$ 61.61$ & $\$ 23.23$ \\
\hline Ramipril & $\$ 80.84$ & $\$ 49.07$ \\
\hline Trandolapril & $\$ 95.80$ & $\$ 31.90$ \\
\hline All ACE inhibitors & $\$ 103.45$ & $\$ 17.64$ \\
\hline \multicolumn{3}{|c|}{$\mathrm{ARBs}^{\mathrm{a}}$} \\
\hline Candesartan & $\$ 80.18$ & NA \\
\hline Eprosartan & $\$ 97.23$ & NA \\
\hline Irbesartan & $\$ 79.96$ & NA \\
\hline Losartan & $\$ 82.09$ & NA \\
\hline Omesartan & $\$ 74.79$ & NA \\
\hline Telmisartan & $\$ 75.59$ & $\mathrm{NA}$ \\
\hline Valsartan & $\$ 85.62$ & NA \\
\hline All ARBs & $\$ 81.98$ & $\mathrm{NA}$ \\
\hline
\end{tabular}

${ }^{a}$ All drugs include the combination with hydrochlorothiazide except ramipril and perindopril.

$A C E=$ angiotensin-converting enzyme; $A R B=$ angiotensin II receptor blocker . 


\section{FIGURE 2 Average Medicaid Price Per Claim for ACE Inhibitors and ARBs: 1991-2008}

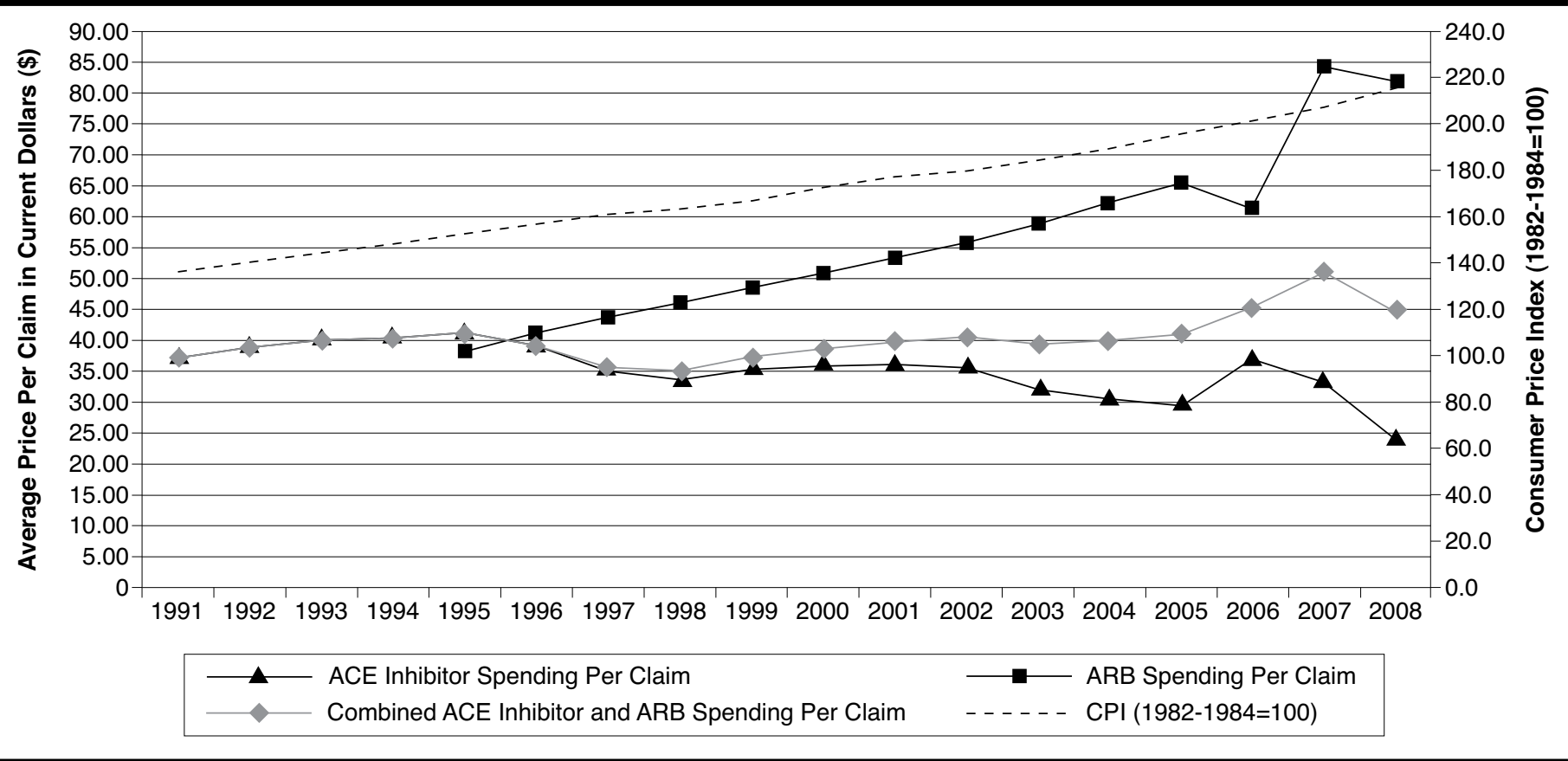

Sources: State Drug Utilization Data found at: http://www.cms.gov/MedicaidDrugRebateProgram/SDUD/list.asp 17 and Consumer Price Index data from the U.S. Department of Labor. ${ }^{19}$

$A C E=$ angiotensin-converting enzyme; $A R B=$ angiotensin II receptor blocker; $C P I=$ Consumer Price Index.

average per-claim prices can be determined for all of the individual ACE inhibitors and ARBs. All of the brand ACE inhibitors and ARBs have had rising prices over time. For example, the price of brand captopril (Capoten) rose from $\$ 40.94$ in 1991 Q1 to $\$ 230.39$ in 2008 Q4, representing a $462.8 \%$ increase, far exceeding the rate of inflation over this period. The price of brand enalapril (Vasotec) rose from $\$ 35.09$ in 1991 Q1 to $\$ 118.36$ in 2008 Q4. The price of brand benazepril went up from $\$ 84.60$ in 2004 Q2 to $\$ 120.63$ in 2008 Q4, representing a $42.6 \%$ increase in just 4.5 years. The price of brand valsartan (Diovan) rose by $97 \%$ from $\$ 44.38$ in 1997 Q1 to $\$ 87.52$ in 2008 Q4.

The average prices of generic captopril, enalapril, and lisinopril showed a steady decline after the entry of additional generic manufacturers. By $2008 \mathrm{Q} 4$, the average price per claim was $\$ 9.93, \$ 29.62$, and $\$ 10.30$ for captopril, enalapril, and lisinopril, respectively. The price of captopril decreased 85\% from $\$ 55.30$ in 1996 Q3 to $\$ 8.28$ in 2005 Q4 as more and more captopril manufacturers entered the market and as the Medicaid programs were able to capture these savings through their reimbursement policies. Table 3 shows average prices for brand and generics for each of the ACE inhibitors and ARBs in 2008. Average reimbursement per claim was higher for several of the brand ACE inhibitors than for the ARBs, but the volumes were, of course, smaller (data not shown).

\section{Discussion}

The \$309.8 million in total Medicaid fee-for-service expenditures on ACE inhibitors and ARBs combined represented approximately $1.5 \%$ of total Medicaid spending of approximately $\$ 21.0$ billion on outpatient prescription drugs (Figure 1). From 1991 to 2005, the year before the Medicaid-Medicare dual eligibles were moved to Medicare Part D, Medicaid's spending on ACE inhibitors and ARBs rose from \$179.2 million to over $\$ 1$ billion (Table 2). There are several reasons for the $458 \%$ increase in spending on ACE inhibitors and ARBs. First, Medicaid enrollment has been increasing over time; in 1991, there were 28.3 million Medicaid beneficiaries, ${ }^{21}$ and by 2005 , there were 45.4 million Medicaid beneficiaries, a $60 \%$ increase in enrollment over this 14 -year period. ${ }^{22}$ In 2006, dual Medicaid-Medicare eligibles were transferred to Medicare Part D for their pharmacy benefit, resulting in a large drop in Medicaid spending for pharmaceuticals. However, the current economic recession that started in December 2007 brought significant job losses, loss of employer-offered health insurance, and a rise in the number of households requiring public assistance. ${ }^{23}$ Second, the prevalence of cardiovascular disease and diabetes has been rising in the United States. The age-adjusted hypertension prevalence over the period 1988 to 1994 was $24.4 \%$ among U.S. adults, rising to $28.9 \%$ during the 
period from 1999 to $2004 .{ }^{24}$ The age-adjusted (child plus adult) diabetes prevalence nearly doubled from $3.0 \%$ in 1991 to $5.7 \%$ in $2007 .{ }^{25}$ Third, the mortality rate for cardiovascular disease has decreased over time; hence, individuals are now taking ACE inhibitors and ARBs, chronic heart medications, for longer periods. Since 1968, cardiovascular disease death rates have fallen in the United States, including a $4.0 \%$ average annual decline in the age-adjusted mortality rate from cardiovascular diseases from 1999 to $2006 .^{11}$ Finally, clinical guidelines and clinical trial results have encouraged increased prescribing of ACE inhibitors and ARBs. ${ }^{1}$

Therefore, the increase in Medicaid spending on ACE inhibitors and ARBs is primarily attributable to increased utilization and not to price increases, although brand prices rose throughout the period. As shown in the last column of Table 2, the average price per claim rose from $\$ 37.24$ in 1991 to $\$ 41.02$ in 2005 , representing just a $10 \%$ increase.

The rise in utilization of these drugs is probably not due to combination therapy with ARBs and ACE inhibitors because combination therapy with these 2 drugs is not encouraged in the United States. ${ }^{26}$ The Val-HeFT (Valsartan Heart Failure Trial) study showed beneficial effects on the combined endpoint of morbidity and mortality in patients who received an ARB in addition to ACE-inhibitor therapy, but subgroup analysis showed deleterious effects on morbidity and mortality when an ARB was given to patients receiving background therapy consisting of an ACE inhibitor plus a beta-blocker. ${ }^{27}$ Moreover, the ONTARGET study suggested that although the combination therapy can cause further reduction of albuminuria relative to ACE inhibitor or ARB monotherapy, the combination therapy had an adverse effect on renal function. ${ }^{10}$ In summarizing the results of the 4 trials devoted to ACE inhibitor and ARB combination therapy, McMurray (2008) concluded that the addition of an ARB to an ACE inhibitor had no benefit and increased the number of adverse events in patients with arterial disease. For patients with heart failure, however, the addition of an ARB might be beneficial. ${ }^{28}$ Generally, in the United States, hypertensive patients take either an ACE inhibitor or ARB but not both

The influences on spending already discussed are largely beyond the control of state Medicaid programs. However, there are 2 Medicaid policies that can have a major impact on spending in these drug classes. First, most state Medicaid programs either require or strongly encourage the use of generic drugs when they become available following patent expiration of their brand counterparts. ${ }^{13}$ In 2008, 92.5\% of Medicaid feefor-service ACE inhibitor pharmacy claims were for generics. However, since the average price per brand ACE inhibitor claim was $\$ 103.45$ compared with an average generic price per claim of $\$ 17.64$, the Medicaid state programs together could have saved $\$ 28.7$ million (for 335,925 brand ACE inhibitor claims) if they had reimbursed for generic claims only in 2008. Second, greater use of ACE inhibitors relative to ARBs would have produced large savings, but this cost outcome would have required interventions such as PA or step-therapy for the ARBs.

Since ACE inhibitors are well tolerated, the step-up approach from ACE inhibitors to ARBs is promising for reducing Medicaid spending. ${ }^{15,16}$ According to our analysis, Medicaid fee-for-service programs could have saved between $\$ 41.8$ million and \$102.3 million with PA for ARBs in 2008, depending on the assumptions made about the ratio of utilization of ARBs. Research reported in this journal by Yokoyama et al. found significant cost savings associated with step-therapy for ARBs implemented in May 2001 in 3 health plans with approximately 1 million members. ${ }^{29}$ The proportion of ACE inhibitor or ARB patients who received an ARB was reduced from 31\% to $18 \%$ in the 12 months following the intervention, producing $\$ 368,000$ in annual savings or $\$ 0.03$ per member per month (PMPM) An accompanying editorial pointed out that the cost savings were actually \$0.06 PMPM if the step-therapy intervention had been followed for a full year, ${ }^{30}$ closer to the cost savings of \$0.11 PMPM reported by Gleason et al. for an ARB step-therapy intervention that was implemented in 2006. ${ }^{31}$ Although some state Medicaid programs such as Massachusetts, Washington, Maine, and Indiana have a PA requirement, not all do. Fischer et al. (2007), compared Medicaid expenditures for states with a PA requirement versus those without and found that step-therapy did indeed reduce ARB use and provided a method to significantly reduce Medicaid spending on antihypertensives. ${ }^{32}$

\section{Limitations}

First among the limitations is the potential invalidity of the Medicaid national database. When we summed all Medicaid fee-for-service claims in 2008 in the national database, we found that Medicaid had a total of $\$ 24.3$ billion in expenditures on all outpatient prescription drugs. This number compares with the $\$ 21.0$ billion National Health Expenditure figure upon which Figure 1 is based, but the $\$ 21$ billion figure apparently includes spending on Medicaid beneficiaries in managed care as well as fee-for-service. Some of the higher cost in the national database of fee-for-service claims is explained by pharmacy reimbursement prior to subtraction of drug manufacturer rebates. However, the proportion of total Medicaid beneficiaries has risen significantly, from only $9.5 \%$ in 1991 to $40.1 \%$ in $1996^{33}$ and $70.9 \%$ in $2008 .^{34}$ We did not determine the extent to which the national Medicaid fee-for-service database that we used includes managed Medicaid pharmacy benefits that are carved out of managed care.

Second, we discovered apparent errors in the national feefor-service database for 5 calendar quarters from the inception of Medicare Part D program in January 2006 through the first quarter of 2007, necessitating our recalculation of expenditures 
to match the claims volume for ARBs and ACE inhibitors. However, these data manipulations did not affect our primary cost savings calculations, which were based on claims data in 2008.

A third limitation of this research is the inability to consider the effects of drug manufacturer rebates in reducing the net cost to the Medicaid programs. The Medicaid Drug Rebate Program, established by the Omnibus Budget Reconciliation Act of 1990, requires a drug manufacturer to enter into and have in effect a national rebate agreement with the secretary of the Department of Health and Human Services in order for states to receive federal funding for outpatient drugs dispensed to Medicaid patients. Rebate percentages are based on average manufacturer prices, and the percentage is higher for innovator drugs than for noninnovator (generic) drugs. ${ }^{35}$ In addition, a number of states have been collecting state-only supplemental rebates in conjunction with a preferred drug list. ${ }^{13}$ Therefore, the claims data that we used in the present study overstate the actual net drug acquisition cost to the Medicaid programs by ignoring rebates and do not include the managed Medicaid pharmacy claims that are not part of the federally administered Medicaid Drug Rebate Program.

\section{Conclusions}

In 2008, state Medicaid programs spent $\$ 309.8$ million on ACE inhibitors and ARBs. Although many factors explaining this expense by affecting utilization (e.g., prevalence of hypertension, heart disease, and diabetes) are beyond the control of program administrators, cost savings can be obtained through a higher percentage of generic drug prescriptions and a higher percentage of ACE inhibitors in the total of ACE inhibitor and ARB utilization. In 2008, Medicaid could have saved up to $\$ 28.7$ million (9\%) through $100 \%$ utilization of generic ACE inhibitors and up to $\$ 142.3$ million from 90\% utilization of ACE inhibitors in the combined class of ARBs and ACE inhibitors.

\section{Authors}

BOYANG BIAN, MS, is a doctoral student in Pharmaceutical Sciences; CHRISTINA M.L. KELTON, PhD, is Professor of Economics and Adjunct Professor of Clinical Pharmacy; JEFF J. GUO, PhD, is Associate Professor of Pharmacoeconomics and Pharmacoepidemiology; and PATRICIA R. WIGLE, PharmD, is Associate Professor of Pharmacy Practice, University of Cincinnati Colleges of Pharmacy and Business, Cincinnati, Ohio.

AUTHOR CORRESPONDENCE: Jeff J. Guo, PhD, University of Cincinnati College of Pharmacy, 3225 Eden Ave., Cincinnati, $\mathrm{OH}$ 45267-0004. Tel.: 513.558.8613; Fax: 513.558.4372;

E-mail:jeff.guo@uc.edu.

\section{DISCLOSURES}

Guo reported consultant relationships with pharmaceutical manufacturers with brand drugs in the class of ACE inhibitors and ARBs, including Novartis, AstraZeneca, and Bristol-Myers Squibb. The other 3 authors reported no financial or other potential conflicts of interest related to the subject of this manuscript. A preliminary version of this study was presented as an unpublished poster at the 15th Annual Meeting of the International Society for Pharmacoeconomics and Outcomes Research in Atlanta, Georgia, in May 2010.

All 4 authors contributed to the study concept and design. Bian collected the data with the assistance of Guo. Bian and Kelton interpreted the data and wrote and revised the manuscript with the assistance of Guo and Wigle.

\section{ACKNOWLEDGMENTS}

The authors appreciate the comments and suggestions of the editors and 3 anonymous reviewers of this manuscript.

\section{REFERENCES}

1. Chobanian AV, Bakris GL, Black HR, et al.; Joint National Committee on Prevention, Detection, Evaluation, and Treatment of High Blood Pressure National Heart, Lung, and Blood Institute; National High Blood Pressure Education Program Coordinating Committee. Seventh report of the Joint National Committee on prevention, detection, evaluation, and treatment of high blood pressure. Hypertension. 2003;42(6):1206-52. Available at: http://www.nhlbi.nih.gov/guidelines/hypertension/jnc7full.pdf. Accessed September 3, 2010.

2. Writing group members, Lloyd-Jones D, Adams RJ, et al.; on behalf of the American Heart Association Statistics Committee and Stroke Statistics Subcommittee. Heart disease \& stroke statistics—2010 update: a report from the American Heart Association. Circulation. 2010;121(7):e46-e215. Epub 2009 Dec 17. Available at: http://circ.ahajournals.org/cgi/reprint/ CIRCULATIONAHA.109.192667. Accessed September 3, 2010.

3. Dall TM, Zhang Y, Chen YJ, Quick WW, Yang WG, Fogli J. The economic burden of diabetes. Health Affairs. 2010;29(2):297-303.

4. Amann B, Tinzmann R, Angelkort B. ACE inhibitors improve diabetic nephropathy through suppression of renal MCP-1. Diabetes Care. 2003;26(8):2421-25. Available at: http://care.diabetesjournals.org/content/26/8/2421.full.pdf + html. Accessed September 3, 2010.

5. Matchar DB, McCrory DC, Orlando LA, et al. Comparative effectiveness of angiotensin-converting enzyme inhibitors (ACEIs) and angiotensin II receptor antagonists (ARBs) for treating essential hypertension. Agency for Healthcare Research and Quality. Comparative Effectiveness Review, no. 10. Publication no. 08-EHC003-EF. November 2007. Available at: http://www. effectivehealthcare.ahrq.gov/ehc/products/12/45/ACEI_ARBFullReport.pdf. Accessed September 3, 2010.

6. U.S. Food and Drug Administration. Center for Drug Evaluation and Research. FDA approved drug products. Available at: http://www.accessdata. fda.gov/scripts/cder/drugsatfda/index.cfm. Accessed September 3, 2010.

7. IMS Health. Top therapeutic classes by U.S. dispensed prescriptions. April 6, 2010. Available at: http://www.imshealth.com/deployedfiles/imshealth/ Global/Content/StaticFile/Top_Line_Data/Top\%20Therapy\%20Classes\%20 by\%20U.S.RXs.pdf. Accessed September 3, 2010.

8. Agency for Healthcare Research and Quality. ACEIs or ARBs for adults with hypertension: clinician's guide. October 2007. Available at: http:// effectivehealthcare.ahrq.gov/ehc/products/12/32/ACEI-ARBClinician.pdf. Accessed September 3, 2010

9. Waknine, Y. FDA approves first generic formulations of losartan for hypertension. Medscape Today. April 9, 2010. Available at: http://www.medscape.com/viewarticle/720003. Accessed September 3, 2010. 
10. ONTARGET Investigators, Yusuf S, Teo KK, Pogue, Dyal L, et al. Telmisartan, ramipril or both in patients at high risk for vascular events. $N$ Engl J Med. 2008;358(15):1547-59.

11. National Heart, Lung, and Blood Institute. Morbidity and mortality: 2009 chart book on cardiovascular, lung, and blood diseases. October 2009 Available at: http://www.nhlbi.nih.gov/resources/docs/2009_ChartBook.pdf. Accessed September 3, 2010.

12. Guo JJ, Jing Y, Nguyen K, Fan H, Li X, Kelton CM. Principal components analysis of drug expenditure and utilisation trends for major therapeutic classes in U.S. Medicaid programmes. J Med Econ. 2008;11(4):671-94.

13. Kaiser Commission on Medicaid and the Uninsured. State Medicaid outpatient prescription drug policies: findings from a national survey, 2005 update. October 8, 2005. Available at: http://www.kff.org/medicaid/7381. cfm. Accessed September 3, 2010.

14. Fischer MA, Avorn J. Economic consequences of underuse of generic drugs: evidence from Medicaid and implications for prescription drug benefit plans. Health Serv Res. 2003;38(4):1051-63.

15. BlueCross BlueShield of Texas. Step therapy guidelines for the City of Houston (COH) employees. March 2009. Available at: http://www.bcbstx. com/provider/pdf/step_therapy_guidelines.pdf. Accessed September 3, 2010.

16. Upper Peninsula Health Plan. Restricted drug classes list. Effective July 1, 2010. Available at: http://www.uphp.com/Pharmacy/ RestDrugListJuly2010.pdf. Accessed September 3, 2010.

17. Centers for Medicare \& Medicaid Services. State drug utilization data. Available at: http://www.cms.gov/MedicaidDrugRebateProgram/SDUD/list. asp. Accessed September 3, 2010.

18. Lewin Group. Medicaid managed-care cost savings-a synthesis of fourteen studies. Final report. Prepared for America's Health Insurance Plans. July 2004. Available at: http://www.ahipresearch.org/pdfs/ MedicaidCostSavings.pdf. Accessed September 3, 2010.

19. Bureau of Labor Statistics. Consumer price index. Available at: http:// www.bls.gov/cpi/. Accessed September 3, 2010.

20. Cox E, Behm A, Mager D. Express Scripts research study findings. 2005 generic drug usage report: executive summary. Available at: http://www. express-scripts.com/research/studies/pharmacybenefitresearch/benefitdesign/docs/genericDrugUsageReport2005.pdf. Accessed September 3, 2010.

21. Zuckerman S, Evans A, Holahan J. Questions for states as they turn to Medicaid managed care. The Urban Institute Series A, No. A-11. August 1997. Available at: http://www.urban.org/UploadedPDF/anf_all.pdf. Accessed September 3, 2010.

22. Centers for Medicaid \& Medicare Services. National summary of Medicaid managed care programs and enrollment as of June 30, 2008. Available at: http://www.cms.gov/MedicaidDataSourcesGenInfo/ downloads/08Trends508.pdf. Accessed September 3, 2010.

23. The National Bureau of Economic Research. NBER Committee confers: no trough announced. April 12, 2010. Available at: http://www.nber.org/ cycles/april2010.pdf. Accessed September 3, 2010.
24. Cutler JA, Sorlie PD, Wolz M, Thom T, Fields LE, Roccella EJ. Trends in hypertension prevalence, awareness, treatment, and control rates in United States adults between 1988-1994 and 1999-2004. Hypertension. 2008;52(5):818-27. Available at: http://hyper.ahajournals.org/cgi/ reprint/52/5/818. Accessed September 3. 2010.

25. Centers for Disease Control \& Prevention. Crude and age-adjusted percentage of civilian, noninstitutionalized population with diagnosed diabetes United States, 1980-2007. July 24, 2009. Available at: http://www.cdc.gov/ diabetes/statistics/prev/national/figage.htm. Accessed September 3, 2010.

26. Baker WL, Coleman CI, Kluger J, Reinhart KM, Talati R, Quercia R, Phung OJ, White CM. Systematic review: comparative effectiveness of angiotensin-converting enzyme inhibitors or angiotensin II-receptor blockers for ischemic heart disease. Ann Intern Med. 2009;151(12):861-71. Available at: http://www.annals.org/content/151/12/861.full.pdf+html. Accessed September 3, 2010

27. Cohn JN, Tognoni G, for the Valsartan Heart Failure Trial Investigators. A randomized trial of the angiotensin-receptor blocker valsartan in chronic heart failure. N Engl J Med. 2001;345(23):1667-75.

28. McMurray JJ. ACE inhibitors in cardiovascular disease-unbeatable? N Engl J Med. 2008;358(15):1615-16. Available at: http://www.nejm.org/doi/ pdf/10.1056/NEJMe0801925. Accessed September 3, 2010.

29. Yokoyama K, Yang W, Preblick R, Frech-Tamas F. Effects of a step-therapy program for angiotensin receptor blockers on antihypertensive medication utilization patterns and cost of drug therapy. J Manag Care Pharm. 2007;13(3):235-44. Available at: http://www.amcp.org/data/jmcp/235-44. pdf.

30. Curtiss FR. Outcomes of sword swallowing and pharmaceutical steptherapy interventions. J Manag Care Pharm. 2007;13(3):284-86. Available at: http://www.amcp.org/data/jmcp/284-86.pdf.

31. Gleason PP. Assessing step-therapy outcomes: a step in the right direction. J Manag Care Pharm. 2007;13(3): 275-75. Available at: http://www. amcp.org/data/jmcp/273-75.pdf.

32. Fischer MA, Choudhry NK, Winkelmayer WC. Impact of Medicaid prior authorization on angiotensin-receptor blockers: can policy promote rational prescribing? Health Aff. (Millwood). 2007;26(3):800-07.

33. Kaiser Commission on Medicaid and the Uninsured. Medicaid and managed care. December 2001. Available at: http://www.kff.org/Medicaid/ upload/Medicaid-and-Managed-Care-Fact-Sheet.pdf. Accessed September 3, 2010.

34. Centers for Medicare \& Medicaid Services. National summary of Medicaid managed care programs and enrollment as of June 30, 2008. Available at: http://www.cms.gov/MedicaidDataSourcesGenInfo/ downloads/08Trends508.pdf. Accessed September 3, 2010.

35. Centers for Medicare $\&$ Medicaid Services. Medicaid drug rebate program: overview. April 20, 2010. Available at: http://www.cms.gov/ MedicaidDrugRebateProgram. Accessed September 3, 2010. 